\title{
THE ALTRUISTIC SIDE OF ARTHUR FLECK AS THE MAIN CHARACTER IN TODD PHILLIPS' JOKER (2019)
}

\author{
Shita Dewi Ratih Permatasari ${ }^{\left.a^{*}\right)}$ \\ a) Universitas Pakuan, Bogor, Indonesia \\ ${ }^{*}$ Corresponding Author: shitapermata@unpak.ac.id
}

Article history: received 28 January 2020; revised 09 February 2020; accepted 16 February 2020

\begin{abstract}
As a movie character Arthur Fleck, also known as Joker, is represented as a supervillain as well as the archenemy of Batman. He is depicted as a cruel murderer, with a clown-like appearance suffering from mental-illness, who spread the fear and terror in the Gotham city. Using descriptive analysis, characterization and Stephen G. Post's Altruism and Altruistic Love theory by focusing on Fleck as the main character in this film, this paper is trying to see how he develops his characteristics and reveals his altruistic side. Based on the analysis it is revealed that Fleck has a dynamic character. Even though he is represented as a heartless murderer, his altruistic side is specifically disclosed in some certain aspects
\end{abstract}

Keywords: Joker, characterization, altruistic love, dynamic character.

\section{INTRODUCTION}

As a product of popular culture, a film is the representation of people's everyday lives in reality as it almost brings entire aspects of social reality and reaches into all aspects of our individual and collective lives. Villarejo (2007) stated that the dynamism of a film rests on its capacity to arrange and rearrange time and motion [1]. Therefore, it reveals its various dimensions that are deeply political, psychological, philosophical, aesthetic, personal, industrial, technological, and so forth. Film also cannot be separated from literature. According to Mario Klarer (1999) film is a semi-textual genre that are both influenced by and exerting influence on literature and literary criticism. In addition, it is also predetermined by literary techniques; conversely, literary practice developed under particular features under the impact of a film[2]. He then added that even though film has its own specific characteristics and terminology, it can be analyzed by drawing on methods of literary criticism as it is closely related to the traditional approaches to textual studies. Nancy Kaplan, as quoted by Wahyudi (2017), stated that in the past literature was closely linked to printing technology, while in the modern times literature is not only textual, but also visual, electronic, nonverbal, and gestural[3]. Therefore, film can be said as an object of literary studies.

Raymond Williams (1983) argued that as a popular culture, a film can simply be defined as one of those objects or practices that are well-liked by a lot of people[4]. Following this idea, it is assumed that the story in the film can relate to human beings. In other words, though a film is just a reflection of reality, by analyzing the cinematic elements as well as the narrative aspects of a film, we can also analyze the human aspects presented in the film.
One of the human aspects presented in the film is the psychological aspect. Film always features the character along with its characteristics and dynamic development in its story. The main character in the film is presented in different ways, one of which is presented to perform dynamic and complex characteristics in other words, the main character usually goes through experiences and problems in life that potentially influence his or her psychological characteristics.

The film that features the development of human characteristics is Todd Phillips' Joker (2019). It tells the story of the supervillain, Arthur Fleck (Joaquin Phoenix), known as Joker. This film also serves as the biography of Arthur Fleck, a poor citizen with a condition living in Gotham and working as a party clown under "Haha's" agency. Arthur lives with and takes care of his delusional mother, Penny Fleck. He often consults his mental illness to psychiatrist. He's got his medication from the health service provided by the local government. The conflict starts when his advertisement board is stolen by the street children. Afterwards, his friend, working under the same agency, lends him a gun to protect himself. He then got fired because of illegal handgun possession when he was entertaining kids in the hospital. At the same time, he found out the government stop giving him health service.

On his way back home, Arthur gets bullied by three young businessmen who are teasing a woman on the train. Undoubtedly, he shot and killed them. The murder triggers the mass rally to protest the social gap in the city where all the protesters wear clown mask to represent the antigovernment movement. The political situation in Gotham city is getting heated as Thomas Wayne, who is a politician, billionaire, mayoral candidate, and Bruce Wayne's father (also known as Batman) was killed by the protesters. Later, Arthur opened his mother's secret letter and it was written in his mom's letter that Thomas Wayne is his father. Her mother finally said that she used to work with Thomas 
Wayne and had an affair with him. Knowing the fact that his mother keeps the secret away from him, Fleck gets disappointed and starts finding the truth himself. Fleck got more depressed when Thomas Wayne told him that he was an adopted child and his mother suffered from delusion. Due to these bad past experiences, his psychological characteristics change and he becomes a different, cruel, and impulsive person who brutally kills people whom he doesn't like.

As a film, Joker has been the object of literary research. In her article called Reclamation of History: A Tryst with Subaltern Studies, Marxist Criticism and Chaos Theory in the Movie Joker, Shreelakshmi compared two films The Dark Knight and Joker. In her analysis, she unveils the illusion and ideology propagated by the Dark Knight that presents Joker as a supervillain. Meanwhile, Joker serves as an apology which highlights the background story of Arthur Fleck who gives voice to the suppressed and the oppressed that have been unfairly treated and neglected by the local government[5]. Rahman and Nor (2019) only focuses on sadistic actions done by Joker that could potentially be dangerous and psychologically affect its viewers, particularly young people. Moreover, the analysis only focuses on Joker's negative traits as well as violence that is against Islamic teachings[6]. Meanwhile, Marzuqi said that Joker (2019) serves as a social criticism when Joker is represented as a symbol of resistance and class struggles between the oppressed and the perpetrators. As a supervillain, Joker was born as a result of the social injustice[7].

It is clear that Arthur Fleck's characteristics develop through the story. Therefore, this study aims to see how the characteristics of Arthur Fleck develops and how his altruistic side is expressed through several events in the film. In addition, this study will also reveal why Arthur's psychological characteristics develop or change.

\section{RESEARCH METHODS}

The method of descriptive analysis is utilized by elaborating the facts in the film that supported by analysis. This method also applies the intrinsic aspects of film narrative by focusing on the main character and characterization. In this study, the life of the main character will be systematically written along with the conflicts and problems he experiences to see how he develops his characters. Besides that, this study also uses the extrinsic approach, that is Stephen G. Post concept of altruism, to support the analysis. This concept is used to provide the reasons why the main character develops.

The analysis starts from elaborating the development of the main character, Arthur Fleck along with some events and conflicts in the film that influence how he develops as a dynamic character. The snippets of related dialogues which support the analysis will be theoretically analyzed to reveal the character change. Afterwards, the altruistic sides of the main character which highlights the positive sides of Arthur Fleck.
Laurence Perrine (1988) classified character into two categories, flat characters and round characters[8]. While flat characters are characterized by one or two traits, the round characters are complex and many-sided. Furthermore, Perrine argued that fictional characters might be divided into static or developing. While the static character is the same sort of person from the beginning to the end of the story, the developing or dynamic character undergoes a permanent change in some aspect of character, personality, and outlook. In addition, E.M Forster (1927) in Abrams (1999) introduced two classical terms to distinguish flat and round characters. When a flat character (also called a type, or "two dimensional") is built around a single idea or quality and is presented without much individualizing detail, a round character is complex in temperament and motivation and is represented with subtle particularity. Therefore, such a character is difficult to describe with any adequacy as a person in real life and is potentially capable of surprising us [9]. These definitions will be utilized to prove that Arthur Fleck is a dynamic character.

Burhan Nurgiyantoro (2005) explains the differences between character and characterization. While character refers to the person (protagonist or antagonist), the characterization refers to how the characters in the story are given certain traits and characteristics[10]. Moreover, Jones (1968) also states that characterization is the clear depiction of each characters presented in the story.

Stephen G. Post's theory and concept of Altruism is also used to reveal the main character's altruistic side. In general, altruism refers to the act of caring that an individual does to give others the needs and happiness. Basically, altruistic side lies in every human being and is part of the human nature. Post (2002) argued that when a person expresses his altruistic love, it means that he cares about other people[11]. It is because altruistic love is linked to care, sympathy that one gives to others suffering from injustice and unfairness. Post also said that it is uniquely human meaning that it is intentionally done by a person to others. It is related to care, action, and compassion. Therefore, altruistic love is the epitome of human altruism.

\section{RESULTS AND DISCUSSION}

\section{The Character Change of Arthur Fleck}

The human traits and characteristics lie on the characters in the story. Sudjiman (1988) stated that though characters are fictious, they actually have similar characteristics as well as traits in real life[12]. Therefore, it can be concluded that through the representation of characters in the film we can learn and understand the complexities of human character along with its development. Before revealing the altruistic sides of the main character, Arthur Fleck's characterization as well as characteristics will be analyzed to see how they develop through events that he experiences in the story. Afterwards, the altruist sides of the main character will be presented in the analysis. 
Arthur Fleck is a dynamic character as his characteristics are very complex and develop through the story. It can be proven from the changes he performs in the story. As a poor citizen having a certain health condition and living with his delusional mother, Arthur is actually a kind and patient person. It is proven when in the beginning of the story the street children stole his board sign, hardly hit his face with the board and beat him up until he became physically weak. Though he was brutally beaten, Arthur didn't take it seriously. As seen in the following dialogue between he and his colleague, Randall.

Randal: "You Okay? I heard the beatdown you took. Fucking savages."

Fleck: "It was just a bunch of kids. I should have left it alone"

Randall: "No. They'll take everything from you if you do that. All the crazy shit out there. They're animals.

That he likes kids can also be identified when he met a boy in the bus on his way back home. The boy sitting right in front of him looked at him and tried to play with him. Knowing that he was interested in playing with him, Arthur made jokes and played peekaboo until the mother got angry and mistook it as he tried to bother her son, but he wasn't angry and gave her a card telling her that he had a condition. Besides that, Arthur is also a kind-hearted person and it can be seen when Randall offered him a handgun to protect him from bad people. He simply replied that he's not supposed to have gun as he knew that gun possession can potentially put him in big troubles.

The kind-hearted Arthur can also be seen in his relationship with his mother. He really loves his mother, Penny Fleck and is really responsible for taking care of her even though he himself has a condition. After coming back from work, he always spends his time talking to his mother, watching tv together, preparing her meal, and bathing her. When his mother is worried about their poor living condition, Arthur tells her not to worry about money as he is sure that he can make a good comedian to collect money and financially support their life.

As the story goes on, Arthur characteristics develops. Continuously his character changes through the story. He begins to become a different person when he gets fired from "Haha's" agency where he works as a party clown. He was caught for having handgun when he was doing a clown show in the kid's hospital. The gun that he got from his friend, Randall, fell onto the floor and the kids saw it. Though he denied and said to his boss that it was part of his clown act, he was reported for the gun possession and ended up getting fired. Later he also figured out that Randall intentionally gave him the gun in order to put him in troubles. Randall also slandered him by telling his boss that Arthur bought the gun from him intentionally.

Another scene which shows how his characteristics change is when Arthur was on his way back home after he got fired. When he was on the train, he saw three businessmen were trying to seduce the lone woman. Due to his condition he unintentionally laughed at them. Consequently, they mocked and beat him up. With no hesitation he brutally shot and killed them and then ran away. The day after the "weak" Arthur became a different person. He was so confident of expressing his thoughts. It can be seen when Arthur went to his office after getting fired due to handgun possession. Arthur knew that he was slandered by Randall so that he confidently and sarcastically accused him of making his boss get him fired. As seen in the following dialogue:

Gary: "Hey Arthur. I heard what happened. Sorry mate" Randall: "Yeah. It doesn't seem fair, getting fired like that.

Man 1: "Did you really bring a gun to the children's hospital, Artie? What the fuck would you do that for?

Man 2: "Is that part of your new act, Arthur? If your dancing doesn't do the trick, you're gonna shoot yourself."

Arthur: "Why don't you ask Randall about it? It was his gun."

Randall: "What?"

Arthur: "I still owe you for that, don't I"

Randall: "What the fuck are you talking about? Stop talking out of your ass, Art"

Arthur: "Oh no. I forgot to punch out"

From the above dialogue, it can be inferred that Arthur was so confident of suspecting him for why he got fired. Knowing that he was betrayed, Arthur sarcastically expressed his dislikes towards him.

Arthur's character change can also be identified when he figured out that his mother, Penny Fleck, was caught lying to him. He accidently opened his mom's secret letter and found out that Thomas Wayne, the billionaire as well as the Mayoral Candidate of Gotham City had an affair with Penny. Penny said that she used to work with Thomas Wayne as a secretary, but their relationship ended up unhappily. Due to societal expectations and the social gap between them Thomas Wayne was forced to abandon her Knowing the truth, Arthur was either shocked and disappointed with his mother. as seen in the following dialogue:

Penny: "You're gonna kill me. You're gonna give me a heart attack."

Arthur: "Don't give me your ...."

[pounding on door]

Penny: "No.No. I'm not talking to you until you stop being angry!"

Arthur: "Okay. I'm not angry mom."

This made Arthur confront Thomas Wayne directly in person. Surprisingly, Thomas denied what Penny said in her letter. He violently asserted that he was his biological father and told him that Arthur was adopted by Penny and that she also suffered from being delusional. Being disappointed with Thomas' revelations, he went to Arkham Hospital when 
Penny was taken care. After stealing her medical records, he found out that Thomas was telling the truth. The medical records showed that his mother had been committed to the insane asylum. The files stated that she often had a delusion as Thomas' secret love. In the files, Arthur also found that there was an adoption records for an unnamed baby. After successfully finding out what happened to his past life, Arthur was so depressed and disappointed. He then killed his mother who had been unconscious and hospitalized. $\mathrm{He}$ assumed that everybody, including his mother, never made him happy so that he became cruel and evil and also began to hate his mother. As seen in the following dialogue before he killed Penny in the hospital room:

Arthur: "Hey Penny. Penny Fleck. I always hated that name. You know how you used to tell me that my laugh was a condition? That there was something wrong with me? There isn't. That's the real me."

Penny: "Happy."

Arthur: "Happy. Hmm. I haven't been happy. One minute of my entire fucking life. You know what's funny? You know what really makes me laugh? I used to think that my life was a tragedy. But now I realize. It's a fucking comedy.

Arthur had been through a lot of unpleasant experiences that made him disappointed. This made him a cruel and impulsive person. He killed everyone who didn't understand his condition. It can also be seen when he shot Murray Franklin in a live show as he blamed him to have killed the men on the train without understanding how he felt inside as a man who got bullied by them. Therefore, it can be inferred that Arthur is a dynamic character who develops his characteristics due to unpleasant experiences he'd been through.

\section{The Altruistic Side of the Main Character}

Besides analyzing the character change, this study will also reveal the altruistic side of Arthur Fleck using Stephen G. Post concept of altruism which refers to the act of caring and giving sympathy that an individual does to give others the needs and happiness. As a dynamic character, Arthur changed from being good and nice to evil and impulsive. He began to become cruel due to unpleasant experiences he'd been through in his life. With no hesitation, he kills everyone that doesn't seem nice to him.

Arthur's altruistic side was identified in aspects of sincerity as well as solidarity. When Randall and Gary came to his house, Arthur shot and killed Randall for slandering him, but he didn't kill Gary. Arthur thought that Gary never hurt him and was always nice to him, as seen in the following dialogue:

Gary [screaming]: "What. No. Arthur. No! What. No. why would you do that, Arthur?

Arthur: [breathing rapidly]

[Gary continues sobbing]

Arthur: "Do you watch The Murray Franklin Show?"
Gary: [whimpering] "Yeah" I'm gonna be on tonight. It fucking crazy, innit? Me on the telly."

Gary: "What the fuck, Arthur?"

Arthur: "What? It's okay, Gary. You can go. I'm not gonna hurt you. “"

Gary: "Oh!"

Arthur: "Don't look. Just go. [Arthur yells]

Gary: [crying] "fuck [sighs tearfully]. Hey, Arthur"

Arthur: "Yeah"

Gary: [stammering] "Arthur, can you get the lock?"

Arthur: "Shit. Sorry, Gary. Gary. You were the only one that was ever nice to me"

From the above it can be inferred that Arthur's altruistic side can be seen in aspect of sincerity. He didn't kill Gary since he was always nice to him unconditionally. His altruistic side is also revealed in terms of solidarity aspect. In the last scene of the film story, Arthur was idolized by the protesters who resist the existing political system in Gotham City. Arthur gave his life to represent the majority of people who have been repressed and treated unfairly by the local government. In terms of establishing solidarity which represents the repressed group, he allows himself to be the state enemy and supervillain for the sake of majority. As suggested by Post, it can be inferred as either care or sympathy that he gives to others suffering from injustice and unfairness.

\section{CONCLUSION}

Film can be inferred as a literature genre as it is predetermined by literary techniques and literary study develops particular features under the impact of film. In addition, film can be analyzed using literary criticism methods because the film criticism is closely linked to the approaches of textual approaches. One of human aspects that can be analyzed in film study is the human characteristics as it is closely similar to the people's characteristics in real life. From the analysis of Todd Phillips' Joker (2019), it can be concluded that Arthur Fleck as the main character develops his characteristics. His characteristics have dramatically changed through tragically unpleasant experiences he passed on. From a kind-hearted person, Arthur became a cruel and impulsive man as he has been disappointed by his mother who lied to him, backstabbed by his own friend, and got bullied for his mental condition.

As a human whose nature is complex and develops, it is apparent that Arthur's characteristics is built through multiple and diverse experiences. Even though he is depicted as a cruel and impulsive person, Arthur still has altruistic sides. His altruistic side appears in terms of sincerity and solidarity aspects. He didn't kill his friend, Gary, and set him free as he thought that Gary never treated him bad, betrayed him, and was always nice to him. Arthur's altruistic side was seen when he represented the majority of Gotham citizens who were severely affected by the poor political system. Arthur stood with people who were excluded and considered as social burden. In short, it can be inferred that people's 
characteristics are established through events as well as experiences in the past and they were either explicitly or implicitly presented though characters in the film.

\section{REFERENCES}

[1] A. Villarejo, 2007. Film Studies The Basics. New York: Routledge Taylor and Francis Group.

[2] M. Klarer, 1999. An Introduction to Literary Studies. London \& New York: Routledge Taylor and Francis Group, 1999.

[3] T. Wahyudi, 2017. Membaca Kemungkinan Film Sebagai Objek Penelitian Sastra," Parafrase, vol. Vol 17 No., pp. 33-38.

[4] R. Williams, 1983. Keywords. London: Fontana.

[5] M. Sreelakshmi, 2020. Reclamation of History: A Tryst with Subaltern Studies, Marxist Criticism and Chaos Theory in the Movie Joker," Our Herit., vol. 68, no. 1, pp. 9083-9091.

[6] T. Nor, Syahrudin \& Rahman, 2019. Kekerasan Dalam Film Thriller (Studi Analisis Semiotik Roland Barthes dalam Film 'Joker'),' At-Tadabbur J. Penelit. Sos. Keagamaan, vol. 9 No. 2.

[7] A. Marzuqi, 2019. Joker yang Tak Kuasa Dibenci. EPaper Media Indonesia, Jakarta.

[8] L. Perrine, 1988. Literature: Structure, Sound, and Sense, Fifth Edit. New York: Harcout Brace Jovanovich, Inc.

[9] M. H. Abrams, 1999. A Glossary of Literary Terms, Seventh Ed. Boston: Earl McPeek.

[10] B. Nurgiyantoro, 2005. Teori Pengkajian Fiksi, Fifth. Yogyakarta: Gadjah Mada University Press.

[11] S. G. et. al Post, 2002. Altruism \& Altruistic Love: Science, Philosophy, \& Religion in Dialouge. New York: Oxford University Press.

[12] P. Sudjiman, 1988. Memahami Cerita Rekaan. Jakarta: PT Dunia Pustaka Jaya. 